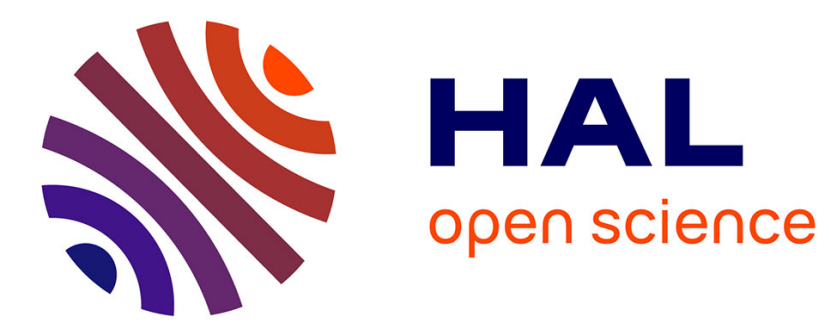

\title{
Study of nitrogen digestion from different hays by the mobile nylon bag technique in horses
}

Didier Macheboeuf, M Marangi, C Poncet, W Martin-Rosset

\section{To cite this version:}

Didier Macheboeuf, M Marangi, C Poncet, W Martin-Rosset. Study of nitrogen digestion from different hays by the mobile nylon bag technique in horses. Annales de zootechnie, 1995, 44 (Suppl1), pp.219-219. hal-00889381

\section{HAL Id: hal-00889381 https://hal.science/hal-00889381}

Submitted on 1 Jan 1995

HAL is a multi-disciplinary open access archive for the deposit and dissemination of scientific research documents, whether they are published or not. The documents may come from teaching and research institutions in France or abroad, or from public or private research centers.
L'archive ouverte pluridisciplinaire HAL, est destinée au dépôt et à la diffusion de documents scientifiques de niveau recherche, publiés ou non, émanant des établissements d'enseignement et de recherche français ou étrangers, des laboratoires publics ou privés. 


\title{
Study of nitrogen digestion from different hays by the mobile nylon bag technique in horses
}

\author{
D Macheboeuf 1, M Marangi 2, C Poncet 1, W Martin-Rosset 1,3 \\ IINRA, Station de recherches sur la nutrition des herbivores. Theix, 63122 St-Genès-Champanelle, \\ France ; ZUniversita di Milano, Faculta di medecina veterinaria, Instituto di alimentazione \\ animale, 120133 Milano, Italy ; ${ }^{3}$ Corresponding author
}

The in sacco nitrogen digestibility of 7 hays of different qualities was measured by the mobile nylon bag technique (MNBT) in fistulated horses in the precæcal part and the total digestive tract. The comparison between in sacco result and in vivo digestibility measured by the conventional technique (total fæces collection), of the same hays was used to validate MNBT.

Four adult horses fitted with a cæcum cannula were used. They were fed at maintenance and received in 2 equal meals $(8: 00,16: 30)$ a ration composed of $30 \%$ barley given first and $70 \%$ hay. Thirty cylindrical nylon bags $(\varnothing 1 \mathrm{~cm}$, length $6 \mathrm{~cm}$, porosity $48 \mu \mathrm{m}$ ) containing $200 \mathrm{mg}$ of ground hay ( $3 \mathrm{~mm}$ mesh) were introduced into stomach of each animal through a nasoœsophagal probe during the morning feed after the concentrate, at each measuring period. These were organised into 2 successive $4 \times 4$ latin squares ( $2 \times 4$ hays including 1 control).

About 15 bags were recovered on arrival in the cæcum $2 \mathrm{~h}$ to $6 \mathrm{~h}$ after introduction (mean retention time, MRT $=4.2 \mathrm{~h} \pm 0.6$ ). The other bags were recovered in fæces between 18 and $60 \mathrm{~h}$ after introduction (MRT $=38.8 \mathrm{~h} \pm 2.7$ ). After washing, the bags were dried (48 $\mathrm{h}$ at $60^{\circ} \mathrm{C}$ ), weighed, and their contents pooled by animal, collection site and hay. Nitrogen content (micro-Kjeldahl), NDF and nitrogen in NDF (N-NDF) were assayed in these bag residues and for the same hays in fæces collected during in vivo digestibility studies. The in sacco digestibility was calculated for precæcal part and total digestive tract. In precæcal part, it affords an estimate of the true digestibility of feed in the stomach and small intestine. In total digestive tract, the $\mathrm{N}$ true digestibility of feed was calculated for the 2 methods in vivo and in sacco after assuming that only dietary $N$ reaching the fæces was $N$ NDF (Glade, 1984, JAS, 58(3), 638-645).

In the total tract, digestibilities of dry matter (not reported) and nitrogen, and estimated true digestibility measured by MNBT correlated significantly with the corresponding in vivo parameters ( $\mathrm{R}^{2}=0.99,0.77,0.75$ respectively). As expected, the in sacco digestibility of $\mathrm{N}$ was higher by 15 to 20 points than its in vivo digestibility. In contrast, the true digestibilities were similar.

In the precæcal part, the in sacco $\mathrm{N}$ digestibility was high $(63.5 \pm 2.6 \%)$, and varied little among hays. It decreased from 67 to $61 \%$ when the $\mathrm{N}-\mathrm{NDF} / \mathrm{N}$ ratio increased. The proportion of feed $\mathrm{N}$ digested before the cæcum varied respectively from 103 to $76 \%$ and from 90 to $69 \%$ when expressed in total \% digestible $\mathrm{N}$ or in \% of truly digestible $\mathrm{N}$.

In conclusion, the MNBT results are consistent with the results obtained with the conventional method on the total tract of the horse. Then it would afford an evaluation of the precæcal digestibility of nitrogen in feed.

\begin{tabular}{|c|c|c|c|c|c|c|c|c|}
\hline Hay & & 1 & 2 & 3 & 4 & 5 & 6 & 7 \\
\hline \multicolumn{9}{|l|}{ Composition } \\
\hline $\mathrm{N}(\% \mathrm{DM})$ & & 0.76 & 1.03 & 1.50 & 1.55 & 1.56 & 2.46 & 2.63 \\
\hline $\mathrm{N}$-ndf / N (\%) & & 40.7 & 50.1 & 50.3 & 59.1 & 50.3 & 53.1 & 62.3 \\
\hline \multicolumn{9}{|l|}{ total tract } \\
\hline \multirow[t]{2}{*}{$\mathrm{N}$ digestibility (\%) } & MNBT & 65.2 & 61.7 & 68.5 & 68.2 & 75.4 & 83.9 & 79.8 \\
\hline & in vivo & 46.6 & 42.0 & 54.5 & 60.1 & 56.7 & 64.7 & 64.6 \\
\hline \multirow[t]{2}{*}{$\mathrm{N}$ True digestibility (\%) } & MNBT & 74.9 & 79.6 & 79.6 & 82.1 & 83.6 & 91.3 & 88.4 \\
\hline & in vivo & 79.4 & 76.5 & 81.2 & 86.2 & 83.7 & 89.6 & 88.4 \\
\hline \multicolumn{9}{|c|}{ Precæcal N digestion (NMBT) } \\
\hline$\% \mathrm{~N}$ intake & & 67.3 & 62.4 & 62.3 & 60.7 & 65.6 & 65.4 & 60.9 \\
\hline$\%$ digestible $\mathrm{N}$ intake & & 103.2 & 101.2 & 90.9 & 89.0 & 87.0 & 78.0 & 76.3 \\
\hline$\%$ truly digestible $\mathrm{N}$ inta & & 89.9 & 78.5 & 78.2 & 73.9 & 78.5 & 71.7 & 68.9 \\
\hline
\end{tabular}

